\title{
Penerapan Metode Role Playing untuk Meningkatkan Hasil Belajar Siswa pada Mata Pelajaran IPS
}

\author{
Zuraidah \\ SD Negeri 101768 Tembung, Percut Sei Tuan, Deli Serdang, Indonesia \\ Diterima Pebruari 2017; Disetujui April 2017; Dipublikasikan Juni 2017
}

\begin{abstract}
Abstrak
Penelitian ini bertujuan untuk meningkatkan hasil belajar siswa pada materi Masalah Sosial dengan menggunakan metode Role Playing kelas IV SD Negeri 101768 Tembung. Penelitian ini menggunakan desain PTK dengan Subjek dalam penelitian ini adalah seluruh sisiwa kelas IV SDN 101768 Tembung Tahun Ajaran 2016 / 2017 yang berjumlah 23 orang. Penelitian ini dilaksanakan dua siklus, yakni siklus I dan siklus II. Setiaap Siklus terdiri dari 4 tahap yaitu perencanaan, pelaksanaan tindakan, observasi dan refleksi. Teknik pengumpulan data yang digunakan adalah tes dan observasi. Soal yang diberikan 3 kali yaitu tes awal, siklus I, siklus II, sedangkan observasi meliputi aktivitas guru dan siswa dalam proses pembelajaran. Dimana nilai standar ketuntasan belajarnya adalah 65. Apabila nilai siswa kurang dari 65, maka siswa dikatakan belum tuntas. Pada saat dilaksanakan Siklus I dapat diketahui bahwa dari 23 siswa orang siswa sebanyak 9 orang siswa $(39,13 \%)$ yang mendapat hasil belajar tidak tuntas dan sebanyak 14 orang siswa $(60,87 \%)$ yang masuk dalam kategori tuntas dengan rata-rata kelas sebesar 63,48 . Jika dibandingkan dengan nilai tes awal, maka telah terjadi peningkatan hasil belajar siswa. Berdasarkan tes Siklus II dapat diketahui sebanyak 2 orang siswa $(8,70 \%)$ yang belum tuntas dalam belajar dan sebanyak 21 orang siswa $(91,30 \%)$ yang tuntas dalam belajar dengan nilai rata-rata kelas sebesar 79,57. Setelah dilakukan pembelajaran dan tes pada Siklus II diperoleh peningkatan hasil belajar siswa dalam pembelajaran IPS dan sekaligus menandakan bahwa tidak perlu lagi diadakan Siklus berikutnya. Berdasarkan hasil penelitian dapat disimpulkan bahwa. Penerapan metode role playing untuk meningkatkan hasil belajar siswa pada mata pelajaran IPS di kelas IV SD Negeri 101768 Tembung T.A 2016/2017.
\end{abstract}

Kata Kunci: Model Pembelajaran Role Playing dan Hasil Belajar Siswa

\begin{abstract}
This study aims to improve student learning outcomes on Social Problem material by using the method of Role Playing class IV SD Negeri 101768 Tembung. This research use design of PTK with Subject in this research is all side of class IV SDN 101768 Tembung Year Ajisi 2016/2017 which amounts 23 people. This research was conducted two cycles, namely cycle I and cycle II. Setiaap Cycle consists of 4 stages of planning, action implementation, observation and reflection. Data collection techniques used are tests and observations. Problem given 3 times the initial test, cycle I, cycle II, while the observation includes the activities of teachers and students in the learning process. Where the value of learning completeness standard is 65. If the student score is less than 65, then the student is said not yet completed. At the time of Cycle I can be seen that of 23 students of students as many as 9 students (39.13\%) who got the results of learning is not complete and as many as 14 students (60.87\%) who entered in the category of complete with average class of 63.48. When compared with the initial test score, then there has been an increase in student learning outcomes. Based on the Cycle II test, 2 students (8.70\%) were unfinished in the study and as many as 21 students (91.30\%) completed in the study with grade point average of 79.57. After the learning and test in Cycle II, the students' learning outcomes in the IPS lesson and the next cycle are no longer necessary. Based on the results of the study can be concluded that. Implementation of role playing method to improve student learning outcomes in social studies subjects in class IV SD Negeri 101768 Tembung T.A 2016/2017. Keywords: Role Playing Learning Model and Student Learning Outcomes
\end{abstract}

How to Cite: Zuraidah, (2017), Penerapan Metode Role Playing untuk Meningkatkan Hasil Belajar Siswa pada Mata Pelajaran IPS, Anthropos: Jurnal Antropologi Sosial dan Budaya, 3 (1): 37-42 


\section{PENDAHULUAN}

Pada dasarnya semua guru menginginkan kompetensi tercapai dalam setiap proses pembelajaran. Guru merupakan salah satu unsur dalam proses belajar mengajar karena walaupun kurikulum disajikan secara sempurna, sarana terpenuhi dengan baik, apabila guru belum berkualitas maka proses belajar mengajar belum dikatakan baik. Pada mata pelajaran IPS khususnya, guru megalami kesulitan dalam mengajar karena murid SD merasa bosan dengan dengan pelajaran yang berisikan materi terus menerus. Sehingga murid kurang berminat dalam pelajaran tersebut.

IPS adalah bidang studi yang mempelajari ,menelaah ,menganalisis masalah sosial dimasyarakat dengan meninjau dari berbagai aspek kehidupan atau suatu perpaduan yang ada di masyarakat. Ilmu Pengetahuan Sosial (IPS) juga membahas hubungan antara manusia dengan lingkungannya lingkungan masayarakat dimana anak didik tumbuh dan berkembang sebagai bagian dari masyarakat ,dihadapkan pada berbagai permasalahan yang ada dan terjadi di lingkungan sekitarnya .

Di dalam peningkatan mutu pendidikan pada masa sekarang ini, perlu diiringi proses belajar mengajar ,di dalam proses belajar mengajar harus memiliki metode agar siswa dapat belajar secara efektif dan efisien serta mengenai tujuan yang diharapkan. Salah satu langkah untuk strategi itu ialah menguasai tekhnik-tekhnik pengajaran atau biasa disebut metode pengajaran .

Melalui Observasi yang dilakukan Peniliti di kelas IV SD Negeri 101768 Tembung ,di jumpai sebagian besar siswa tidak suka dengan mata pelajaran IPS sehingga sebagian nilai yang diperoleh kurang memuaskan. Pemahaman siswa pada pokok bahasan Masalah sosial masih sangat rendah . Dari hasil observasi dan diskusi dengan guru, di kelas IV SD Negeri 101768 Tembung Kecamatan Percut Sei Tuan.Kabupaten Deli Serdang. terdapat data bahwa rata - rata nilai belajar siswa 4,9 sementara nilai yang diharapkan $\geq 6,5$. Dari 23 siswa hanya 5 orang siswa yang nilai hasil belajarnya memuaskan, 8 orang siswa yang nilai hasil belajarnya pas-pasan, dan 18 orang siswa nilai hasil belajarnya di bawah rata-rata.

Kurangnya perhatian siswa dalam mengikuti proses pembelajaran IPS dan dikarenakan guru sering menggunakan metode ceramah dan bertaya saja kepada siswa dan siswa hanya mendengarkan penjelasan dari guru hal ini mengakibatkan siswa cenderung pasif, terhadap maaeri yang diterangkan dan siswa juga masih belum sepenuhnya mengungkapkan pendapat belum sepenuhnya mampu mengungkapkan ide dan pendapt mereka .

Dalam upaya meningkatkan hasil belajar siswa perlu diciptakan suatu kondisi belajar yang dapat mengembangkan daya fikir siswa ,melibatkan lebih banyak keaktifan siswa ,sehingga belajar khususnya IPS di sekolah merupakan pelajaran yang menyenangkan bagi siswa ,salah satu upaya yang dapat dilakukan untuk meningkatkan hasil belajar siswa adaalah dengan menggunakan metode role playing (bernain peran) dalam pembelajaran . metode Role Playing (bermain peran) adalah penyajian bahan dengan cara memperlihatkan peragaan ,baik dalam bentuk uraian maupun kenyataan .

Belajar merupakan salah satu bentuk perilaku yang sangat penting bagi kelangsungan hidup manusia. Belajar membantu manusia menyesuaikan diri (adaptasi) dengan lingkungannya. Belajar merupakan kegiatan setiap orang. Belajar sering diartikan sebagai suatu proses perubahan itu dapat berupa kognitif, afekif, dan psikomotorik dan nantinya diharapkan siswa mampu memecahkan masalah-masalah atau tuntunan hidupnya.

Pada saat melakukan kegiatan belajar terjadi proses berfikir yang melibatkan kegiatan mental, dan terjadi hubungan informasiinformasi yang diterima sehinngga timbul suatu pemahaman dan penguasaan materi yang di berikan. Dengan adanya pemahaman dan penguasaan yang didapat setelah proses belajar mengajar maka siswa telah memahami suatu perubahan dari yang tidak diketahui menjadi diketahui. Perubahan inilah yang disebut dengan hasil belajar. 
Menurut Winkel dalam Purwanto, (2011:45) "hasil belajar adalah perubahan yang mengakibatkan manusia berubah dalam sikap dan tingkah lakunya. Dimyati dan Mudjiono (2009: 250) menyatakan bahwa "Hasil belajar adalah hal yang dapat dipandang dari dua sisi yaitu dilihat dari sisi siswa dan sisi guru . Dari sisi siswa hasil belajar merupakan tingkat perkembangan mental yang lebih baik bila dibandingkan dengan saat sebelum proses belajar mengajar. Sedangkan dilihat dari sisi guru hasil belajar merupakan saat terselesaikannya bahan pelajarannya tersebut".

Berdasarkan pendapat diatas peneliti dapat menyimpulkan bahwa metode adalah cara yang digunakan oleh guru dalam melaksanakan kegiatan belajar mengajar di kelas sebagai upaya untuk mencapai tujuan pembelajaran yang telah ditetapkan. Metode mempunyai andil yang sangat besar dalam kegiatan belajar mengajar. Penggunaan metode yang sesuai dan tepat dapat menghasilkan berlangsungmya kegiatan belajar mengajar yang efektif.

Keunggulan metode role Playing menurut Syaiful Bahri dan Azwan zain yaitu: 1) Siswa melatih dirinya untuk memahami dan mengingat isi bahan yang akan didramakan. 2) Siswa akan terlati untuk berinisiatif dan berkreatif. 3) Bakat yang terdapat pada siswa dapat dipupuk sehingga dimungkinkan akan muncul atau tumbuh bibit seni drama dari sekolah. 4) Kerja sama antar pemain dapat ditumbuhkan dan dibina dengan sebaikbaiknya. 5) Siswa memperoleh kebiasaan untuk menerima dan membagi tanggung jawab dengan sesamanya. 6) Bahas lisan siswa dapat dibina menjadi bahasa yang baik agar mudah dipahami orang lain. 7) Peserta didik akan mengerti sosio psychologis.

Di samping Keunggulannya, metode Role Playing juga memiliki kelemahannya, kelemahan metode Role Playing menurut syaiful bahri dan azwan zain antara lain : 1) Sebagian Besar anak yang tidak ikut bermain darama mereka menjadi kurang kreatif. 2)Banyak memakan waktu. 3) Memerlukan Tempat yang cukup luas. 4) Sering kelas lain terganngu oleh suara pemain dan para penonton yang kadangkadang bertepuk tangan.

\section{METODE PENELITIAN}

Penelitian dilaksanakan di kelas IV SD Negeri 101768 Tembung. Penelitian ini dilaksanakan selama 3 bulan,bulan Pebruari sampai dengan bulan April 2017, mulai dari kegiatan persiapan, pelaksanaan tindakan, sampai penulisan laporan. Dalam waktu 3 bulan, dapat dilihat perkembangan hasil belajar siswa pada mata pelajaran IPS dengan metode Role Playing.

Jenis penelitian yang dilakukan dalam penelitian ini adalah Penilitian Tindakan Kelas (PTK) atau dengan nama lain Classroom Action Research yaitu suatu model penelitian yang dikembangkan di kelas sesuai dengan kebutuhan atau permasalahan yang terjadi di dalam kelas tersebut. Sesuai dengan jenis penelitian ini, maka penelitian ini memiliki tahap-tahap penelitian beberapa siklus. Setiap siklus mempunyai tahhapan yang sama.

Pada tahap perencanaan ini yang dilakukan adaah merencanakan tindakan yang akan dilakukan yaitu berupa skenario pembelajaran. Kegiatan yang dilakukan dalam tahap perencanaan siklus I adalah sebagai berikut: 1. Melakukan pengamatan secara langsung keadaan sekolah, baik ruang kelas,guru maupun peserta didik. 2. Mengidentifikasi masalah dan menentukan alternatif pemecahannya. 3. Membuat Rencana Pelaksanaan Pembelajaran (RPP) 4. Mempersipkan pembelajaran dengan menggunakan Metode Role Playing. 5. Menyusun sekenario bermain peran atau Role Playing pada materi pokok masalah sosial. 6 . Membuat lembar observasi untuk mengamati pembelajaran. 7. Menyusun alat evaluasi untuk mengetahui tingkat keberhasilan siswa.

Tahap Pelaksanaaan Tindakan dilaksanakan pembelajaran yang sesuai dengan scenario yang sudah disusun yaitu menggunakan metode Role Playing Kegiatan yang dilakukan pada tahap ini adalah sebagai berikut: 1. Menjelaskan kepada siswa tentang materi masalah sosial serta contohnya . 2. Menjelaskan kepada siswa langkah- 
langkah pembelajaran dengan menggunakan metode bermain peran. $3 . \quad$ Pemanasan yaitu guru memotivasi siswa dengan memperkenalkan atau menjelaskan pentingnya mempelajari masalah sosial. 4. Memilih pemain, guru mengajak siswa membahas karakter dari setiap pemain dan menunjuk siapa yang akan memainkannya. 5. Menyiapkan pengamat guru meminta seluruh siswa yang tidak turut jadi pemain peran sebagai pengamat. 6. Menata Panggung, guru mendiskusikan dengan siswa di mana dan bagaimana peran ini akan dimainkan. Apa saja kebutuhan yang diperlukan. Penataan panggung ini dapat sederhana atau kompleks, yang paling sederhana adalah hanya membahas skenario (tanpa dialog lengkap) yang menggambarkan urutan permainan peran. Konsep sederhana memungkinkan untuk dilakukan karena intinya bukan dilakukan karena intinya bukan kemewahan panggung, tetapi proses bermain peran itu sendiri. 7 . Memainkan Peran, guru meminta dan mengamati siswa memainkan peran yang ada . pada awalnya akan banyak siswa yang masih bingung memainkan peran yang seharusnya ia lakukan. 8. Guru terus memberikan bimbingan dalam metode Role Playing ini. 9. Diskusi dan evaluasi, guru mengajak iswa mendiskusikan permainan yang telah dimainkan dan melakukan evaluasi terhadap peran-peran yang dilakukan. 10. Memainkan peran ulang, guru membimbing dan meminta siswa lainnya untuk memerankan ulang skenario. Seharusnya pada permainan kedua ini akan berjalan dengan baik. Siswa dapat memainkan perannya lebih sesuai dengan skenario. 11. Berbagi pengalaman dan kesimpulan, Guru membimbing siswa untuk barbagi pengalaman tentang peran yang telah mereka lakukan dan membimbing siswa membuat kesimpulan dari materi yang telah dipelajari

Tahap observasi dilakukan selama proses pembelajaran untuk mengetahui hasil belajar siswa dan kesesuaian tindakan yang dilakukan guru (peneliti) dengan rencana yang telah disusun. Pada tahap observasi ini yang menjadi pengamat adalah guru kelas IV, dengan menggunakan format lembar observasi yang telah disiapkan

\section{HASIL DAN PEMBAHASAN}

Berdasarkan hasil dan pembahasan penelitian, maka dalam penelitian ditemukan hal-hal sebagai berikut: Sebelum diberikan tindakan, siswa diberikan Pre Test yang terlampir pada lampiran 3, dimana 3 siswa $(17,39 \%)$ yang mencapai syarat ketuntasan belajar, dari 20 siswa $(82,61 \%)$ belum tuntas dan dari Pre Test diperoleh nilai rata-rata kelas 49,13 .

Berdasarkan Pre Test tersebut maka upaya yang dilakukan untuk meningkatkan hasil belajar siswa tersebut dengan menggunakan Metode Role Playing Setelah Siklus I ini, guru memberikan Post Test I pada lampiran 6 diperoleh bahwa 14 siswa $(60,87 \%)$ telah mencapai tingkat ketuntasan belajar dan 9 siswa $(39,13 \%)$ belum mencapai tingkat ketuntasan belajar yang diharapkan dengan nilai rata-rata kelas 63,48. Akan tetapi masih ada siswa yang hanya menjawab soal dengan mengingat-ingat jawaban dari test awal yang diberikan kepadanya, sehingga menyebabkan siswa masih belum tuntas semuanya. Pada hasil pengamatan observasi guru, pada siklus I guru masuk dalam kategori cukup baik dengan persentase $71,87 \%$.

Berdasarkan hasil Post Test I upaya dilakukan untuk meningkatkan hasil belajar tersebut adalah dengan penggunaan metode Role Playing yang di optimalkan pelaksanaanya. Pada pemberian tindakan Post Test II pada lampiran 7 diperoleh 21 siswa (91,30\%) telah mencapai tingkat ketuntasan belajar dan 2 orang siswa $(8,7 \%)$ belum mencapai tingkat ketuntasan belajar dengan nilai rata-rata kelas 79,57. Disini siswa tidak lagi hanya mengingat jawaban dari test yang telah diberikan, tetapi mereka telah memahami dan menguasai materi yang telah diajarkan guru dengan menggunakan metode Role Playing . Pada hasil observasi guru yang dilakukan oleh pengamat pada siklus II masuk dalam kategori baik. Dan hal ini dapat disimpulkan bahwa pembelajaran yang diberikan oleh guru berhasil dengan persentase $88,90 \%$. 
Tabel Peningkatan Hasil Belajar Siswa

\begin{tabular}{|l|l|l|l|l|}
\hline No. & $\begin{array}{l}\text { Hasil } \\
\text { Belajar }\end{array}$ & $\begin{array}{l}\text { Nilai } \\
\text { Rata- } \\
\text { rata }\end{array}$ & $\begin{array}{l}\text { Persentase } \\
\text { Ketuntasan } \\
(\%)\end{array}$ & $\begin{array}{l}\text { Siswa } \\
\text { Yang } \\
\text { Tuntas }\end{array}$ \\
\hline 1. & $\begin{array}{l}\text { Pre } \\
\text { Test }\end{array}$ & 49,13 & $17,39 \%$ & $\begin{array}{l}3 \\
\text { Orang }\end{array}$ \\
\hline 2. & $\begin{array}{l}\text { Post } \\
\text { Test I }\end{array}$ & 63,48 & $60,87 \%$ & $\begin{array}{l}14 \\
\text { Orang }\end{array}$ \\
\hline 3. & $\begin{array}{l}\text { Post } \\
\text { Test II }\end{array}$ & 79,57 & $91,30 \%$ & $\begin{array}{l}21 \\
\text { Orang }\end{array}$ \\
\hline
\end{tabular}

Dari tabel di atas dapat dilihat bahwa siswa yang tuntas belajar sebelum Siklus sebanyak 3 siswa $(17,39 \%)$ yang tuntas pada Siklus I sebanyak 14 siswa $(60,87 \%)$ sedangkan Siklus II sebanyak 21 siswa (91,30\%).

Lebih jelasnya peningkatan hasil belajar siswa dapat dilihat dari rata-rata nilai saat test awal, hasil belajar Siklus I dan pada Siklus II, seperti gambar diagram batang di bawah ini:

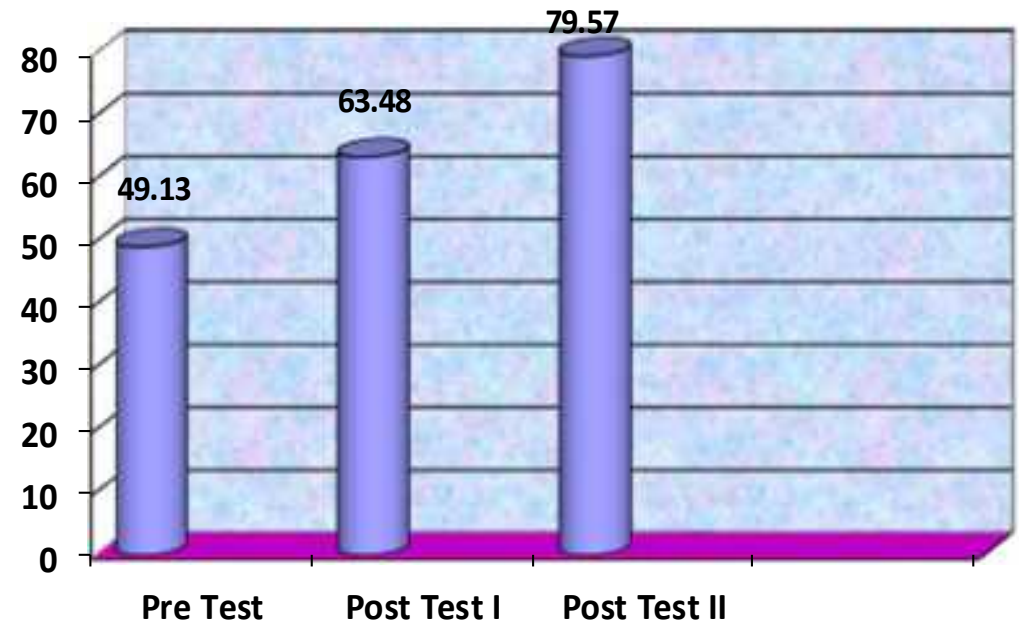

Gambar 3. Grafik Peningkatan Hasil Belajar Siswa

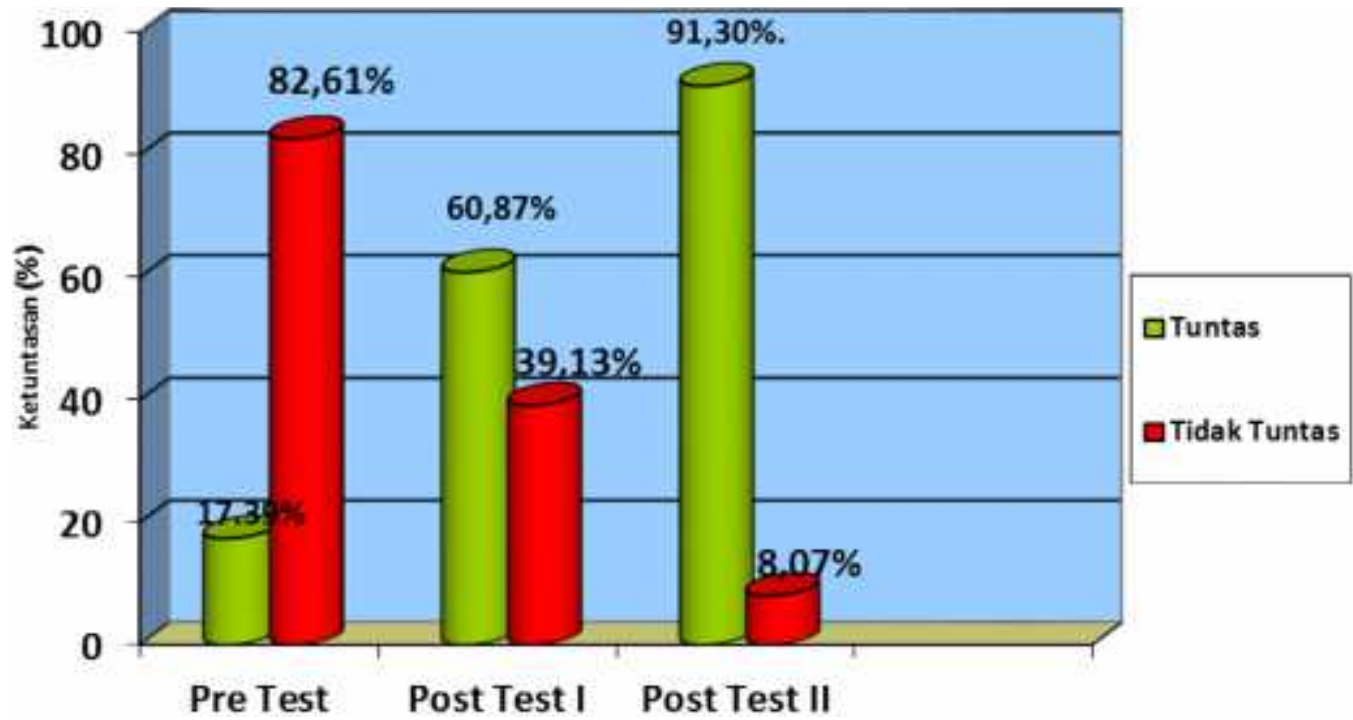

Gambar 4. Grafik Ketuntasan Klasikal Siswa 
Zuraidah, Penerapan Metode Role Playing untuk Meningkatkan Hasil Belajar Siswa pada Mata

\section{KESIMPULAN}

Berdasarkan hasil analisis data dan pembahasan maka diperoleh simpulan sebagai berikut: Rata-rata nilai pada Test Awal sebesar 49,13 , jumlah siswa yang berhasil sebanyak 3 orang $(17,39 \%)$ dan jumlah siswa yang tidak berhasil 20 orang (82,61\%). Rata-rata nilai pada Siklus I sebesar 63,48, jumlah siswa yang berhasil sebanyak 14 orang $(60,87 \%)$ dan jumlah siswa yang tidak berhasil sebanyak 9 orang $(39,13 \%)$. Rata-rata nilai pada Siklus II sebesar 79,57, jumlah siswa yang berhasil sebanyak 21 orang $(91,30 \%)$ dan jumlah siswa yang tidak berhasil sebanyak 2 orang $(8,7 \%)$. Dari poin-poin di atas dapat disimpulkan bahwa setelah dilakukan tindakan pada setiap siklus terdapat peningkatan hasil belajar siswa dengan penggunaan metodeRole Playing

\section{DAFTAR PUSTAKA}

Abdurrahman, Mulyono. 2003. Pendidikan Bagi Anak Berkesulitan Belajar. Jakarta: PT RINEKA CIPTA
Anas Sudjiono 2006 . Penelitian Tindakan Kelas Jakarta : Bumi Aksara

Arikunto, Suharsimi, dkk. 2010. Penelitian Tindakan Kelas. Jakarta: Bumi Aksara

Damyanti. 2006. Belajar dan Pembelajaran. Jakarta: PT RINEKA CIPTA

Daryanto. 2010. Belajar dan Mengajar. Bandung: Yrama Widya

Dewi, Rosmala. 2009. Penelitian Tindakan Kelas. Medan: Program Pascasarjana UNIMED.

Hamalik, Oemar. 2001. Perencanaan Pengajaran Berdasarkan Pendekatan Sistem. Jakarta: Bumi Aksara

Istarani. 2012. 58 model pembelajaran inovatif. Medan : Media Persada.

Nana Sudjana 2009 Evaluasi Hasil Belajar Jakarta :Rieneka Cipta

Purwanto. 2011. Evaluasi Hasil Belajar. Yogyakarta: Pustaka Belajar

Slameto. 2010. Belajar dan Faktor-Faktor yang Mempengaruhinya. Jakarta: Rineka Cipta

Trianto.2012.Model Pembelajaran Terpadu.Jakarta : Bumi Aksara

(http://id.wikipedia.og/wiki/llmu Pengetahuan sosial 